\title{
IMPLEMENTASI PENDIDIKAN KARAKTER MELALUI \\ PEMBELAJARAN AL ISLAM, KEMUHAMMADIYAHAN \\ DAN BAHASA ARAB KELAS IV
}

\author{
Romadon \\ STKIP Muhammadiyah Bangka Belitung \\ romadon@ @tkipmbb.ac.id
}

\begin{abstract}
Abstrak
Penelitian ini dilatarbelakangi keingintahuan implementasi pembelajaran pendidikan karakter melalui ISMUBA kelas IV SD Muhammadiyah Pangkalpinang. Tujuan penelitian ini mendeskripsikan pembentukan pendidikan karakter religious, rasa ingin tahu, tanggung jawab, bersahabat/komunikatif melalui pembelajaran ISMUBA. Penelitian ini menggunakan pendekatan mix methods. Pengumpulan data melalui observasi, wawancara, angket, dan dokumentasi. Hasil penelitian bahwa pembentukan pendidikan karakter religius melalui pembelajaran ISMUBA, pembentukan pendidikan karakter rasa ingin tahu melalui pembelajaran ISMUBA, pembentukan pendidikan karakter tanggung jawab dapat melalui pembelajaran ISMUBA, pembentukan pendidikan karakter bersahabat/komunikatif melalui pembelajaran ISMUBA. Berdasarkan hasil penelitian dapat disimpulkan bahwa implementasi pembelajaran pendidikan karakter melalui ISMUBA, pembentukan pendidikan karakter religius, rasa ingin tahu, tanggung jawab dan bersahabat/komunikatif terlihat hampir keseluruh terbentuk sepenuhnya.
\end{abstract}

Kata Kunci: Pembelajaran ISMUBA; Pembentukan Karakter.

\section{Abstract}

This research is motivated by the curiosity of the implementation of character education learning through ISMUBA Muhammadiyah Elementary School Pangkalpinang. The objectives of this study are to describe the formation of religious character education through ISMUBA learning, to describe the formation of curiosity character education through ISMUBA learning, to describe the formation of responsibility character education through ISMUBA learning, to describe the formation of character education curiosity through ISMUBA learning, to describe the formation of responsibility character education through ISMUBA learning, to describe the formation of character education curiosity friendly/communicative through ISMUBA learning. Based on the results of the study it can be concluded that the implementation of character education learning through ISMUBA, the formation of religious character education, curiosity, responsibility and friendly/communicative looks almost entirely formed.

Keywords: ISMUBA Learning; Character Building. 


\section{PENDAHULUAN}

Pendidikan adalah suatu usaha manusia dalam rangka memperoleh pengetahuan, serta ilmu ditempuh melalui proses, kemudian dijadikan sebagai dasar manusia itu sendiri dalam besikap dan berperilaku. Salahudin (2011:19) mengatakan bahwa pengertian pendidikan ialah usaha pendewasaan manusia yang hakiki, dan merupakan tuntunan agar anak didik memiliki keahlian dalam bidang kognitif, afektif, dan psikomorik dalam setiap aktivitas dikehidupan sehari-hari. Pendidikan merupakan hal yang paling diutama di dalam kehidupan di zaman sekarang ini.

Pembelajaran pendidikan karakter melalui ISMUBA merupakan suatu kewajiban dilakukan di sekolah dasar maupun sampai perguruan tinggi di persyarikatan Muhammadiyah. Pembelajaran ISMUBA di SD Muhammadiyah Pangkalpinang sudah dilakukan sejak mulai berdiri SD Muhammadiyah Pangkalpinang, tetapi dalam memadukan kurikulum 2013 dilakukan pada tahun akademik 2016/2017. SD Muhammadiyah termasuk salah satu sekolah unggul di Kota Pangkalpinang, terlihat dari akreditasi A, ini menunjukan prestasi yang cukup memuaskan untuk dijadikan referensi sekolah bagi masyarakat. Informasi di dapat bahwa SD Muhammadiyah Pangkalpinang dalam Implementasi ISMUBA dengan kurikulum 2013 membentuk pendidikan karakter siswa.
ISMUBA merupakan pembelajaran yang sangat penting, untuk itu siswa diharapkan mampu membentuk karakter yang diharapkan.

Ditegaskan oleh Perpres Nomor 87 Tahun 2017 tentang Penguatan Pendidikan Karakter disebutkan, Penguatan Pendidikan Karakter (PPK) adalah gerakan pendidikan di bawah tanggung jawab satuan pendidikan untuk memperkuat karakter peserta didik melalui harmonisasi olah hati, olah rasa, olah pikir, dan olah raga dengan pelibatan dan kerja sama antara satuan pendidikan, keluarga, dan masyarakat sebagai bagian dari Gerakan Nasional Revolusi Mental (GNRM).

$$
\text { Menurut Boedhowi }
$$
menyatakan bahwa ISMUBA merupakan ciri khusus dan keunggulan bagi sekolah, dan madrasah Muhammadiyah merupakan pendidikan Islam modern yang integratifholistik, berupa sekolah umum yang mengintegrasikan ilmu-ilmu tentang agama Islam dan diajarkan ISMUBA untuk mengintegrasikan ilmu-ilmu umum. Pendidikan ini memiliki ciri utama, yakni diajarkan ilmu agama Islam. Kedua, ISMUBA bagi sekolah dan madrasah Muhammadiyah merupakan ciri khusus dan keunggulan yang wajib ada di lembaga Kemuhammadiyahan. Rancangan pendidikan Islam modern yang integratif-holistik, menghasilkan lulusan yang menguasai ilmu pengetahuan umum sesuai jenjang, dan 
Edutainment : Jurnal Ilmu Pendidikan dan Kependidikan

Volume 7 Nomor 2 Edisi Juli-Desember 2019

agama Islam, kemuhammadiyahan serta bahasa Arab. Artinya bahwa ISMUBA sudah mengintegrasi pada kurikulum 2013 serta dengan mata pelajaran khusus maupun pembelajaran secara umum.

Yaumi (2016:10) mengemukakan bahwa pendidikan karakter adalah usaha yang disengaja untuk mengembangkan karakter yang baik berdasarkan nilai-nilai inti yang baik untuk individu dan baik untuk masyarakat. Sejalan dengan itu, Daryanto, dkk (2013:43) mengemukakan bahwa pendidikan karakter adalah segala sesuatunya yang dilakukan guru, yang mampu mempengaruhi karakter peserta didik.

Jadi, dari beberapa pengertian di atas dapat disimpulkan bahwa pendidikan karakter merupakan suatu usaha sadar maupun tidak sadar untuk mengembangkan nilai-nilai karakter yang baik berguna untuk masa depan, baik itu untuk individu maupun pada masyarakat umum.

Menurut Baedhowi (2017:19) tentang prinsip ISMUBA, maka yang penting ditekankan ialah belajar untuk beriman dan bertakwa kepada Allah Swt, belajar untuk memahami dan menghayati, belajar untuk mampu melaksanakan dan berbuat secara efektif, belajar untuk hidup bersama dan berguna bagi orang lain, belajar untuk membangun dan menemukan jati diri, dan perilaku yang baik.

\section{METODE PENELITIAN}

Jenis penelitian ini menggunakan mix method dengan tujuan untuk mengetahui implementasi pembelajaran pendidikan pembentukan karakter melalui ISMUBA di kelas IV SD Muhammadiyah Pangkalpinang. Menurut Sugiyono $(2017: 18)$ mengemukakan bahwa metode penelitian pendekatan mix method adalah metode penelitian yang mengkombinasikan antara dua metode sekaligus, yakni kualitatif dan kuantitatif dalam suatu kegiatan peneltian, sehingga akan diperoleh data komprehensif, valid, reliable, dan objektif. Data pada penelitian yang akan dikumpulkan melalui kuisioner, wawancara dengan partisipan secara mendalam, observasi dan dokumentasi. Pendekatan mix method digunakan dalam penelitian ini yang diperoleh dari data kuisioner, wawancara, observasi dan dokumentasi, karena data yang dikumpulkan berbentuk angka-angka dideskripsikan, sehingga data yang didapatkan lebih tepat dan akurat.

\section{Subjek dan Lokasi Penelitian}

Subjek penelitian ini Kepala Sekolah, Guru, dan siswa di kelas IV SD Muhammadiyah Pangkalpinang. Lokasi penelitian ini di kelas IV SD Muhammadiyah Pangkalpinang.

\section{Teknik Pengumpulan Data}

Teknik pengumpulan data penelitian ini: Observasi, menurut Agustinova (2015:36) 


\section{Edutainment : Jurnal Ilmu Pendidikan dan Kependidikan}

Volume 7 Nomor 2 Edisi Juli-Desember 2019

menyatakan bahwa observasi adalah (2017:140) wawancara tidak terstruktur pengamatan terhadap suatu objek yang adalah wawancara yang bebas, dimana diteliti baik secara langsung maupun tidak peneliti tidak menggunakan pedoman langsung dengan melibatkan semua indera wawancara yang telah tersusun secara (penglihatan, pendengaran, penciuman, sistematis dan lengkap untuk pengumpulan pembau, perasa) untuk memperoleh data data. Pertanyaan wawancara ditujukan yang harus dikumpulkan dalam penelitian.

Adapun yang dilakukan adalah observasi atau pengamatan secara langsung terhadap kegiatan yang dilaksanakan di SD Muhammadiyah Pangkalpinang. Dengan metode ini, peneliti akan mengetahui secara jelas bagaimana Implementasi pembelajaran pendidikan pembentukan melalui ISMUBA di kelas IV SD Muhammadiyah Pangkalpinang

Wawancara, menurut Sugiyono (2017:137) mengemukakan bahwa wawancara adalah teknik pengumpulan data apabila ingin melakukan studi pendahuluan untuk menemukan permasalahan yang harus diteliti, dan juga apabila peneliti ingin mengetahui hal-hal dari respon yang lebih mendalam dan jumlah responden sedikit/kecil.

Untuk memperoleh data yang lengkap dan untuk memahami Implementasi pembelajaran pendidikan karakter melalui ISMUBA di kelas IV SD Muhammadiyah Pangkalpinang, maka digunakan metode wawancara. Metode wawancara yang digunakan adalah wawancara yang bersifat tidak terstruktur yang digunakan sebagai teknik pengumpulan data. Menurut Sugiyono kepada kepala sekolah, guru mata pelajaran ISMUBA, dan sebagian murid. Adapun pelaksanaan kegiatan pewawancara membawa pedoman yang merupakan hanya garis besar tentang hal-hal yang akan ditanyakan.

Dokumentasi, menurut Sugiyono (2015:82) mengatakan bahwa dokumen merupakan catatan peristiwa yang sudah berlalu. Dokumen biasa berbentuk tulisan, gambar, atau akar-akar monumental dari seseorang. Dalam penelitian ini menggunakan dokumentasi itu berupa fotofoto pada saat penelitian berlangsung, sehingga tidak ada manipulasi saat penelitian dilakukan. Dokumen dipergunakan sebagai alat untuk penunjang kelengkapan data dalam penelitian, sehingga data penelitian valid dan benar adanya.

Kuesioner, menurut Sugiyono (2017:142) mengatakan bahwa kuesioner merupakan teknik pengumpulan data yang dilakukan dengan cara memberi seperangkat pertanyaan atau pernyataan tertulis kepada responden untuk dijawab.

Pengumpulan data mengunakan kuesioner dilakukan peneliti dengan cara memberikan pertanyaan-pertanyaan atau 


\section{Edutainment : Jurnal Ilmu Pendidikan dan Kependidikan}

Volume 7 Nomor 2 Edisi Juli-Desember 2019

pentaan berkaitan dengan sub variabel pada pembelajaran pendidikan pembentukan karakter al-Islam, kemuhammadiyahan, dan bahasa melalui ISMUBA di kelas IV SD Muhammadiyah Pangkalpinang.

Jenis kuisioner yang digunakan skala Guttman, menyajikan item-item yang akan dinilai oleh individu sebagai persetujuan atau ketidaksetujuan, dan diberikan melalui jawaban Ya/Tidak. Tujuan dari analisis ini untuk menggambarkan dimensi tunggal bagi pertanan dan subjek yang diteliti. Skala Guttman mengandung penekanan melalui ketegasan jawaban dari responden, sehingga tidak ada alasan lebih lanjut.

\section{Teknik Analisis Data}

Teknik analisis data yang digunakan dalam penelitian ini yaitu teknik Miles dan Huberman dalam Agustinova (2015:63) menyatakan bahwa analisis data kualitatif dilakukan dengan mengorganisasikan data, menjabarkan ke dalam unit-unit, melakukan sintesa, menyusun ke dalam pola, memilih mana yang penting dan mana yang akan dikaji, dimulai sejak belum penelitian memasuki lapangan, dilanjutkan pada saat penelitian berada dilapangan secara interaktif, dan berlangsung terus menerus sampai tuntas, sehingga data jenuh.

Ukuran kejenuhan data ditandai dengan tidak diperoleh lagi data atau informasi baru. Aktivitas dalam analisis meliputi reduksi data (data reduction), penyajian data (data display), serta penarikan kesimpulan, dan verifikasi (conclusion drawing/verification).

Reduksi Data (Data Reduction), dalam tahap ini, peneliti melakukan pencarian dan pengumpulan data sebanyak-banyaknya di lapangan. Data yang tela dicari dan dikumpul akan ditulis atau dicatat secara teliti dan rinci. Setelah data dicatat secara rinci dan teliti, barulah data tersebut dirangkum dan dipilih mana hal-hal yang penting, lalu mulai mencari tema. Data dicari dan dikumpul melalui observasi, wawancara dan angket.

Penyajian Data (Data Display), setelah data direduksi dan ketemu tema dan polanya, maka langkah selanjutnya adalah mendisplaykan data. Dalam penelitian ini penyajian data dilakukan peneliti dalam bentuk gambar. Data disajikan dalam bentuk gambar, agar data tersusun secara sistematis dan semakin mudah dipahami.

Penarikan Kesimpulan dan Verifikasi (Conclusion Drawing/Verification), langkah ketiga dalam analisis data kualitatif yaitu penarikan kesimpulan dan verifikasi. Pada tahap ini, peneliti menarik kesimpulan dari hasil penelitian yang telah dilakukan dengan didukung bukti-bukti yang valid.

\section{HASIL DAN PEMBAHASAN}

Adapun hasil penelitian berupa data deskriptif kualitatif diperoleh dari observasi, wawancara, angket, dan dokumentasi, kepada kepala sekolah, guru, siswa dan orang tua siswa di SD Muhammadiyah Pangkalpinang tentang implementasi 


\section{Edutainment : Jurnal Ilmu Pendidikan dan Kependidikan}

Volume 7 Nomor 2 Edisi Juli-Desember 2019

pembelajaran pendidikan pembentukan karakter melalui ISMUBA di kelas IV SD Muhammadiyah Pangkalpinang”. Data diperoleh dari hasil observasi, wawancara, kuisioner, dan dokumentasi. Berdasarkan observasi dilakukan penelitian untuk melihat Implementasi pembelajaran pendidikan pembentukan karakter melalui ISMUBA di dalam dan di luar pembelajaran. Peneliti melihat bahwa pembentukan religius tercermin melaui kegiatan siswa berdoa, sebelum mulai pembelajaran ISMUBA yang dipimpin oleh ketua kelas. Guru memberikan kesempatan kepada semua peserta didik untuk melaksanakan ibadah shalat wajib, seperti shalat zuhur dan asar di sekolah serta shalat sunnah, seperti shalat duha.

Kegiatan shalat wajib bagi siswa lakilaki dilaksanakan berjamaah di mushola, sedangkan bagi siswa perempuan dilaksanakan di kelas atau di mushola, setelah siswa laki-laki selesai. Sedangkan untuk shalat Duha dilaksanakan rutin setiap hari Rabu dan Jumat di lapangan, diikuti oleh seluruh peserta didik. Pembelajaran pendidikan pembentukan karakter religius juga terlihat saat siswa bertemu guru di luar jam pelajaran, siswa menyapa guru dan mengucapkan salam disertai besalaman dan mencium tangan. Pendidikan pembentukan karakter religius juga tercermin dari infak dan shodaqoh yang dilaksanakan setiap hari Jumat, siswa menyisikan sebagian uang untuk dikumpulkan, kemudian disalurkan bagi yang membutuhkan.

Pendidikan pembentukan karakter rasa ingin tahu dapat terlihat dari saat kegiatan pembelajaran di dalam kelas ISMUBA, dimana guru memberikan kesempatan bertanya pada semua siswa saat pembelajaran, dan saat berdiskusi dengan metode kelompok berlangsung siswa berani mengemukakan pendapat dihadapan semua teman kelas.

Selanjutnya, untuk karakter tanggung jawab tercermin dari saat siswa mengerjakan tugas hafalan, dan tugas lain diberikan guru pada pembelajaran pendidikan karakter melalui ISMUBA, serta keikutsertaan siswa dalam kegiatan sekolah terprogram, seperti ada salah satunya TPA yang wajib diikuti oleh siswa, dibimbing oleh wali kelasnya masing-masing. Pembentukan karakter tanggung jawab juga terlihat dari siswa melaksanakan piket kelas sesuai dengan jadwal yang telah ditentukan dan dibuat oleh guru/wali kelas masing-masing.

Selanjutnya, pembentukan karakter bersahabat/komunikatif terlihat dari bagaimana hubungan guru dengan siswa. Guru menganggap siswa sebagai lak seorang teman sendiri. Saat siswa mengalami kesulitan, siswa selalu meminta bimbingan belajar dalam pembelajaran ISMUBA, dan siswa saling membantu satu sama lain bila mengalami kesulitan dalam pembelajaran. 
Pembelajaran pendidikan pembentukan karakter melalui ISMUBA pada siswa tidak hanya melalui observasi, juga melalui wawancara kepada siswa, guru mata pembelajaran kelas IV dan kepala sekolah SD, hasil angket kepada orang tua siswa kelas IV Muhammadiyah Pangkalpinang, adapun hasil wawancara dan angket sebagai berikut:

Wawancara kepada siswa, uraian di atas didukung oleh pendapat Haziq Azka Smil selaku siswa kelas IV, pembentukan karakter religius ananda bisa melafalkan doa sebelum belajar dan sesudah belajar biasa. Selanjutnya, ananda berpamitan pada orang tua sebelum berangkat ke sekolah, karena harus menghormati orang yang lebih tua. Selanjutnya, ananda saat bertemu orang yang lebih tua menghormati dengan cara bersalaman, karena harus menghargai orang yang lebih tua. Selanjutnya, apakah ananda melaksanakan ibadah, seperti shalat wajib dan sunnah di sekolah karena perintah Allah Swt? Selanjutnya, berinfak atau sedekah waktu tertimpa musibah, agar dapat membantu orang lain.

Pembentukan karakter rasa ingin tahu ananda, sering bertanya pada guru mengenai pembelajaran yang belum dimengerti di sekolah, agar kita dapat ilmu yang banyak. Selanjutnya, ananda sering menyampaikan pendapat saat pembelajaran.

Pembentukan karakter tanggung jawab ananda mengerjakan tugas yang diberikan oleh guru seperti PR, hafalan, dan lain-lain. Selanjutnya, ananda melaksanakan piket kelas sesuai dengan jadwal yang telah dibuat, karena piket kelas merupakan suatu kewajiban siswa. Selanjutnya, ananda mengikuti program kegiatan yang ada di sekolah, seperti TPA dan lain-lain, karena kita harus mengikuti aturan.

Pembentukan

karakter

bersahabat/komunikatif, ananda menganganggap guru sebagai teman, karena guru telah mendidik kami semua. Selanjutnya, ananda meminta bimbingan kepada guru bila mengalami kesulitan pada pembelajaran ISMUBA, agar mendapatkan pembelajaran yang lebih baik.

Selanjunya, triangulasi kepada Zaza siswa kelas IV berkaitan melafalkan doa sebelum belajar dan sesudah belajar, mengatakan bahwa untuk proses pembentukan karakter religious, ananda dapat melafalkan doa sebelum belajar.

Pembentukan karakter tanggung jawab ananda mengerjakan tugas yang diberikan oleh guru seperti PR, hafalan. Selanjutnya, ananda melaksanakan piket kelas sesuai dengan jadwal yang telah dibuat, karena kebersihan sebagian dari iman. Selanjutnya, ananda mengikuti kegiatan yang ada di sekolah, seperti TPA.

Pembentukan karakter rasa ingin tahu, ananda sering bertanya pada guru mengenai pembelajaran yang belum dimengerti di sekolah kadang-kadang bertanya kepada 


\section{Edutainment : Jurnal Ilmu Pendidikan dan Kependidikan}

Volume 7 Nomor 2 Edisi Juli-Desember 2019

guru jika ada pelajaran yang belum dimengerti. Selanjutnya, ananda sering menyampaikan pendapat waktu belajar.

Pembentukan karakter bersahabat/komunikatif ananda menganggap guru sebagai teman, selalu meminta bimbingan kepada guru bila mengalami kesulitan pada pembelajaran ISMUBA.

Uraian di atas juga diperkuat oleh pembentukan karakter religious, ananda bisa melafalkan doa sebelum belajar dan sesudah belajar, selanjutnya, ananda berpamitan pada orang tua sebelum berangkat ke sekolah.

Berdasarkan hasil Triangulasi kepada siswa Taqytuzahra Ariny berkaitan melafalkan doa sebelum belajar dan sesudah belajar, mengatakan bahwa pembentukan karakter religious, ananda biasa melafalkan doa sebelum dan sesudah belajar. Selanjutnya, ananda berpamitan pada orang tua sebelum berangkat ke sekolah, berpamitan pada orang tua sebelum berangkat ke sekolah. Selanjutnya, ananda melaksanakan ibadah, seperti shalat wajib dan sunnah di sekolah. Selanjutnya, berinfak atau sedekah jika ada tertimpa musibah.

Pembentukan karakter rasa ingin tahu, ananda sering bertanya pada guru mengenai pembelajaran belum dimengerti di sekolah. Selanjutnya, ananda sering menyampaikan pendapat saat pembelajaran.

Pembentukan karakter tanggung jawab, ananda mengerjakan tugas yang diberikan oleh guru seperti PR, hafalan dan lain-lain. Selanjutnya, ananda melaksanakan piket kelas sesuai dengan jadwal yang telah dibuat, jadwal piket dibuat untuk pembelajaran disiplin. Selanjutnya, ananda mengikuti program kegiatan ada di sekolah seperti TPA dan lain-lain, wajib ikuti eskul untuk menambah pengetahuan.

Pembentukan karakter bersahabat/komunikatif, ananda menganggap guru sebagai teman tidak, karena menganggap guru sebagai pengganti orang tua untuk menggali ilmu. Selanjutnya, ananda meminta bimbingan kepada guru bila mengalami kesulitan pada pembelajaran ISMUBA, guru selalu memberikan ilmu dan membimbing. Selanjutnya, apakah ananda menjenguk teman apabila ada yang sedang sakit? wajib dijenguk bila ada yang sedang sakit dan menghibur teman yang sedang kesusahan.

Wawancara guru mata pelajaran alIslam dan kemuhammadihan kelas IV, untuk memperkuat pendapat telah ada juga dikemukakan oleh bapak Wildan Isa Arrezy selaku guru mata pelajaran ISMUBA kelas IV di SD Muhammadiyah Pangkalpinang mengatakan bahwa pelaksaanan pembelajaan ISMUBA terhadap pembentukan karakter religius, rasa ingin tahu, tanggung jawab dan bersahabat/komunikatif.

Wawancara dengan Wildan Isa Arrezy mengatakan bahwa untuk membentuk karakter religius dalam pelaksaanaan 


\section{Edutainment : Jurnal Ilmu Pendidikan dan Kependidikan}

Volume 7 Nomor 2 Edisi Juli-Desember 2019

pembelajaran ISMUBA ialah dengan cara menyuruh siswa berdoa sebelum dan sesudah belajar, serta memberikan penyadaran akan penting doa bagi umat Islam. Karakter religius juga terbentuk dalam menumbukan sikap saling menghormati siswa setiap bertemu guru dengan cara mengingatkan siswa bahwa guru merupakan orang tua di sekolah, dan hormat kepada guru sama dengan hormat kepada orang tua, juga merupakan adab menuntut ilmu, dan termasuk dalam janji pelajar Muhammadiyah. Untuk menumbuhkan karakter religius ialah dengan cara membiasakan siswa untuk melaksanakan ibadah itu dengan dengan mengingatkan siswa bahwa tujuan dari penciptaan manusia itu salah satunya untuk beribadah, tanpa menambah-nambah dari yang disampaikan Rasullullah Saw terlebih menguranginya. Serta, menumbuhkan karakter religius ialah dengan membiasakan siswa untuk berinfak atau sedekah dengan cara mengingatkan siswa bahwa sedekah itu bagian dari ciri orang beriman sesuai dengan pembelajaran ISMUBA yang dipelajari.

Karakter rasa ingin tahu dalam ISMUBA ialah memberikan kesempatan bertanya yang sama pada siswa dengan cara merangsang siswa untuk bertanya dengan memberikan materi yang dapat menumbuhkan keingintahuan siswa. Selanjutnya, untuk membuat siswa berani mengemukakan pendapat ialah dengan cara bertanya kepada siswa dengan pertanyaan yang membuat siswa berpikir kritis.

Untuk menumbuhkan karakter tanggung jawab dengan cara guru memberikan pemahaman bahwa tugas yang diberikan itu, akan menjadi bekal mereka untuk mendapatkan nilai kebaikan, serta mengarahkan siswa agar mengikuti program sekolah, seperti TPA dan lain-lain, yakni dengan cara memberikan pemahaman bahwa kegiatan yang ada di sekolah merupakan bagian dari pembelajaran. Selanjutnya, untuk menumbuhkan karakter tanggung jawab itu dengan cara guru mengajak siswa melaksanakan tugas piket kelas sesuai dengan jadwal yang telah ditentukan dengan cara memberikan pemahaman bahwa tugas piket merupakan cara untuk menjadikan ruangan belajar menjadi bersih, karena kebersihan merupakan sebagian dari iman.

Menumbuhkan

karakter bersahabat/komunikatif dalam pembelajaran ISMUBA, siswa menganggap gurunya menjadi teman baginya itu dengan cara menganggap siswa tanpa merendahkan potensi dimiliki para siswa. Kemudian, untuk menumbuhkan karakter bersahabat/komunikatif, bagaimana cara guru membimbing siswa yang mengalami kesulitan? dengan cara memberikan semangat untuk fokus belajar dan jangan putus asa. Selanjutnya, bagaimana cara guru menumbuhkan kebiasaan siswa untuk saling tolong menolong sesuai dengan 


\section{Edutainment : Jurnal Ilmu Pendidikan dan Kependidikan}

Volume 7 Nomor 2 Edisi Juli-Desember 2019

pembelajaran ISMUBA? melalui pemahaman tentang ukhuwah islamiah, sehingga siswa paham bahwa sesama muslim atau kafir pun harus tolong menolong.

Berdasarkan hasil Triangulasi kepada bapak Harnandy berkaitan pelaksanaan pembelajaran ISMUBA terhadap pembentukan karakter religius, rasa ingin tahu, tanggung jawab, dan bersahabat/komunikatif menyatakan bahwa pembentuk karakter religius dalam pelaksaanaan pembelajaran ISMUBA, berdoa sebelum dan sesudah pembelajaran dilakukan, dengan cara mengajak siswa dengan pembiasaan mengaji dan membaca doa sebelum belajar, karena berdoa tidak hanya dalam pembelajaran saja, akan tetapi di luar pembelajaran juga harus berdoa, supaya melatih kebiasaan siswa dalam melakukan segala hal harus berdoa terlebih dahulu, kemudian dengan cara menumbuhkan sikap saling menghormati setiap bertemu guru dengan cara mengajak siswa saat bertemu orang yang lebih tua sesuai dengan adat orang muslim mengucap salam, sapa, senyum dan berjabat tangan. Selanjutnya, membiasakan siswa melakukan shalat duha berjamaah pada hari Rabu dan Jumat dilakukan di lapangan untuk sholat wajib, seperti shalat luhur dan ashar. Kemudian dengan cara membiasakan siswa untuk berinfak atau sedekah dilakukan setiap hari Jumat.
Pembentuk karakter rasa ingin tahu dengan cara memberikan kesempatan bertanya yang sama pada siswa dengan cara memberikan kebebasan yang sama untuk bertanya, dimana keinginan bertanya harus dirangsang, dan agar melatih keberanian siswa salah satunya dengan kegiatan menjadikan siswa sebagai petugas upacara yang dipilih secara acak.

Pembentuk karakter tanggung jawab, bagaimana guru agar siswa mengerjakan tugas yang telah diberikan, seperti hafalan dan lain-lainnya. Cara guru menyuruh siswa mengerjakan tugas, seperti hafalan yang kemudian disetorkan agar anak bertanggung jawab terhadap tugas yang diberikan oleh guru. Selanjutnya, dengan cara guru mengarahkan siswa agar mengikuti program sekolah, seperti TPA yang wajib diikuti oleh siswa dengan cara mengarahkan siswa untuk mengikuti program tersebut, karena sekolah telah menyediakan fasilitas dan pembimbingan. Kemudian, dengan cara mengajak siswa melaksanakan tugas piket kelas sesuai dengan jadwal dengan cara guru memonitor perkembangan siswa apakah sudah piket kelas sesuai dengan jadwal yang telah dibuat dan ikut mendampingi siswa dalam melaksanakan piket kelas.

Membentuk

karakter

bersahabat/komunikatif, siswa menganggap guru sebagai teman dengan cara guru tidak ditakuti oleh siswa, dan guru tidak boleh bersikap kasar terhadap siswa, sebaliknya 


\section{Edutainment : Jurnal Ilmu Pendidikan dan Kependidikan}

Volume 7 Nomor 2 Edisi Juli-Desember 2019

guru menganggap siswa seperti anaknya sendiri, dan siswa menganggap gurunya sebagai bapak atau ibunya sendiri. Selanjutnya, cara guru membimbing siswa saat mengalami kesulitan saat pembelajaran dengan cara apabila jam pembelajaran kurang anak tersebut perlu dibimbing, maka orang tua dipanggil ke sekolah untuk diberikan jam tambahan setelah pulang sekolah. Kemudian, menciptakaan kebiasaan siswa untuk saling tolong menolong dengan cara saat pembelajaran guru membuat kelompok belajar dengan berdiskusi bersama temannya.

Wawancara guru mata pelajaran Bahasa Arab kelas IV, pendapat yang sama juga dikemukakan Eneng Susila Wati selaku guru mata pelajaran bahasa Arab kelas IV di SD Muhammadiyah Pangkalpinang menyatakan bahwa implementasi pembelajaan ISMUBA pada pembentukan karakter religius, rasa ingin tahu, tanggung jawab, dan bersahabat/komunikatif.

Hasil wawancara mengatakan bahwa pembentuk karakter religius dalam pelaksanaan pembelajaran ISMUBA terlihat dari bagaimana siswa berdoa sebelum dan sesudah pembelajaran dilakukan melalui pembiasaan, dan siswa diarahkan untuk berdoa, serta cara agar siswa menghormati saat bertemu guru melalui setiap pagi guru menyambut kedatangan siswa dengan cara bersalaman, sapa, senyum, melalui pembiasaan seperti itu siswa akan merasa dihargai dan dihormati, secara tidak sadar guru telah menumbuhkan sikap saling menghormati, dan selalu harus dinasehati diingatkan bahwa sikap menghormati kepada guru itu sikap terpuji dan diperintahkan oleh Allah Swt.

Untuk karakter religius juga dibentuk melalui bagaimana cara dalam membiasakan siswa untuk melaksanakan ibadah di SD Muhammadiyah bahwa dikhususkan setiap hari Rabu dan Jumat dibiasakan untuk melaksanakan shalat duha berjamaah sebagai pembelajaran kepada siswa tentang cara shalat. Selain shalat duha, sholat luhur dan ashar pun dilaksanakan di sekolah dan dibimbing oleh guru agama.

Selanjutnya, untuk membentuk karakter religius dengan cara membiasakan siswa berinfak atau sedekah di SD Muhammadiyah juga mengajarkan kepada siswa untuk berinfak setiap hari Jumat anak-anak selalu bawa uang untuk diinfakan, dan ustad Wildan ditujukan sebagai pengumpul uang berkeliling setiap kelas untuk mengambil uang infak tersebut.

Kemudian untuk membentuk karakter rasa ingin tahu dengan cara memberikan kesempatan bertanya pada siswa saat pembelajaran pendidikan pembentukan karakter melalui ISMUBA, dengan cara memberikan stimulus kepada siswa agar terpancing rasa ingin tahunya, dan dengan cara membuat siswa berani mengemukakan pendapat saat pembelajaran itu dengan 


\section{Edutainment : Jurnal Ilmu Pendidikan dan Kependidikan}

Volume 7 Nomor 2 Edisi Juli-Desember 2019

memberikan kesempatan untuk mengemukakan pendapat atau ide-ide setiap siswa.

Selanjutnya, untuk membentuk karakter tanggung jawab dengan cara guru memberikan tugas kepada siswa apakah tugas-tugas yang diberikan dikerjakan secara tepat waktu atau tidak, dengan cara penegasaan dan memberikan nilai pada setiap tugas yang diberikan kepada siswa, supaya siswa bersemangat dalam mengerjakan tugas yang diberikan. Kemudian untuk membentuk karakter tanggung jawab dengan cara guru mengarahkan siswa agar mengikuti program sekolah, seperti TPA dan program lainnya yang wajib diikuti siswa, dengan cara mengarahkan siswanya agar mengikuti program tersebut, karena program seperti TPA tadi dapat membantu saat pembelajaran ISMUBA. Selanjutnya, dengan cara guru mengajak siswa melaksanakan tugas piket sesuai dengan jadwal yang telah ditentukan, dengan cara guru membiasakan dan mengajak siswa untuk melaksanakan tugas piket sesuai dengan jadwal secara penuh tanggung jawab.

Selanjutnya, untuk membentuk karakter bersahabat/komunikatif bagaimana agar siswa menganggap guru sebagai teman melalui pendekatan kepada siswa. Kemudian guru memberikan bimbingan kepada siswa ketika mengalami kesulitan pada pembelajaran, dengan cara guru memberikan motivasi, bimbingan, dan memilih metode, serta pendekatan yang berbeda-beda, dibantu dengan media pembelajaran. Selanjutnya, cara guru membiasakan siswa untuk saling tolong menolong sesuai dengan pembelajaran ISMUBA, dengan cara guru memberikan kesempatan siswa untuk memilih teman yang bisa membantunya dalam mengerjakan tugas.

Berdasarkan hasil Trianggulasi kepada siswa berkaitan Implementasi pembelajaan ISMUBA pembentukan karakter religius, rasa ingin tahu, tanggung jawab dan bersahabat/komunikatif menyatakan bahwa pembentukan religius tercermin melaui kegiatan siswa berdoa sebelum pembelajaran dan sesudah pembelajaran ISMUBA dipimpin oleh ketua kelas. Guru memberikan kesempatan kepada semua peserta didik untuk melaksanakan ibadah shalat wajib, seperti shalat luhur dan ashar di sekolah dan shalat sunnah, seperti shalat duha.

Kegiatan shalat wajib bagi siswa lakilaki dilaksanakan berjamaah di mushola, sedangkan bagi siswa perempuan dilaksanakan di kelas atau di mushola setelah siswa laki-laki selesai. Sedangkan untuk shalat Duha dilaksanakan rutin setiap hari Rabu dan Jumat di lapangan yang diikuti oleh seluruh peserta didik. Pembentukan karakter religius juga terlihat dari saat siswa bertemu guru di luar jam pelajaran, saat bertemu guru siswa menyapa guru dan mengucapkan salam disertai besalaman dan 


\section{Edutainment : Jurnal Ilmu Pendidikan dan Kependidikan}

Volume 7 Nomor 2 Edisi Juli-Desember 2019

mencium tangan. Pembentukan karakter religius juga tercermin dari kegiatan infak yang dilaksanakan setiap hari Jumat, siswa menyisikan sebagian uangnya untuk disumbangkan.

Pembentukan karakter rasa ingin tahu dapat terlihat dari kegiatan pembelajaran di dalam kelas pada pembelajaran pendidikan karakter melalui ISMUBA, dimana guru memberikan kesempatan bertanya pada semua siswa saat pembelajaran, dan saat berdiskusi kelompok berlangsung siswa berani mengemukakan pendapatnya dihadapan semua teman kelas.

Selanjutnya, untuk karakter tanggung jawab tercermin dari siswa saat mengerjakan tugas hafalan dan tugas lain yang diberikan guru pada pembelajaran ISMUBA, serta keikutsertaan siswa dalam kegiatan sekolah yang terprogram, seperti yang ada salah satunya TPA yang wajib diikuti oleh siswa, dibimbing oleh wali kelasnya masingmasing. Pembentukan karakter tanggung jawab juga terlihat dari siswa melaksanakan piket kelas sesuai dengan jadwal yang telah ditentukan, dan dibuat oleh guru/wali kelas masing-masing.

Selanjutnya, untuk pembentukan karakter bersahabat/komunikatif dapat terlihat dari bagaimana hubungan guru dengan siswa. Guru menganggap siswa sebagai layaknya seorang temannya sendiri. Saat siswa mengalami kesulitan siswa selalu meminta bimbingan dan siswa saling membantu satu sama lain bila mengalami kesulitan dalam pembelajaran.

Hasil Angket Orang Tua, hasil angket dilakukan kepada orang tua siswa kelas IV disebarkan sebanyak 30 orang secara acak tentang implementasi pembelajaran pendidikan pembentukan karakter melalui ISMUBA di kelas IV SD Muhammadiyah Pangkalpinang adapun hasil sebagai berikut:

Berdasarkan nilai persentase dari Implementasi pembelajaran pendidikan pembentukan karakter melalui ISMUBA di kelas IV SD Muhammadiyah Pangkalpinang dapat dilihat $(85 \%)$.

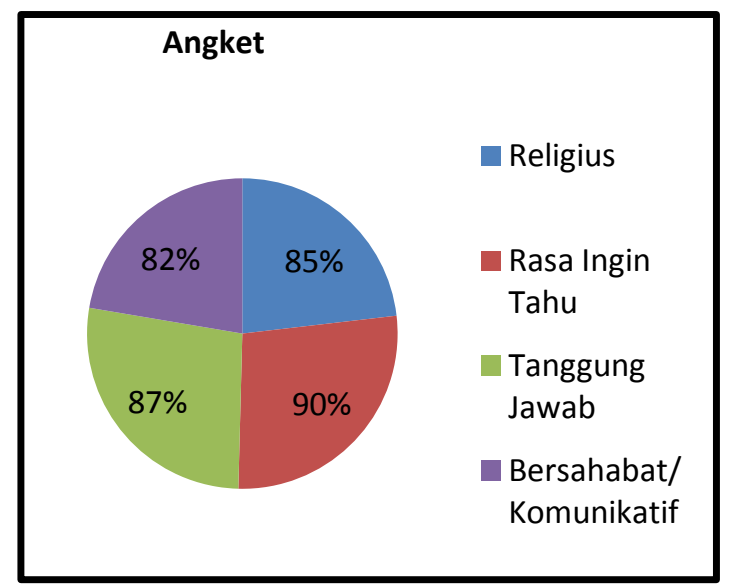

Gambar 1. Angket Implementasi pendidikan pembentukan karakter melalui ISMUBA

$$
\text { Kriteria hampir seluruhnya }
$$
pembentukan karakter religius, karakter rasa ingin tahu mendapat angka persentase (90\%) dengan kriteria hampir seluruhnya, pembentukan karakter tanggung jawab mendapat nilai (87\%) dengan kriteria hampir seluruhnya, pembentukan karakter dan bersahabat/komunikatif angka (82\%) dengan kriteria hampir seluruh pembentukan karakter. 
Edutainment : Jurnal Ilmu Pendidikan dan Kependidikan

Volume 7 Nomor 2 Edisi Juli-Desember 2019

\section{SIMPULAN DAN SARAN}

Berdasarakan hasil penelitian

Implementasi pembelajaran pendidikan karakter melalui ISMUBA di kelas IV SD Muhammadiyah Pangkalpinang, karakter religius, rasa ingin tahu, tanggung jawab dan bersahabat atau komunikatif di kelas IV SD Muhammadiyah Pangkalpinang antara lain:

Pembentukan karakter religius melalui ISMUBA di kelas IV SD Muhammadiyah Pangkalpinang sudah berjalan dengan baik berdasarakan hasil persentase $85 \%$ dengan kriteria hampir seluruhanya pembentuk karakter religius.

Pembentukan karakter rasa ingin tahu melalui ISMUBA pada pembentukan karakter kelas IV SD Muhammadiyah Pangkalpinang sudah berjalan dengan baik dengan hasil persentase $90 \%$ pembentukan karakter rasa ingin tahu.

Pembentukan karakter tanggung jawab melalui ISMUBA ISMUBA pada pembentukan karakter di Kelas IV SD Muhammadiyah Pangkalpinang sudah berjalan dengan baik dengan hasil persentase 87\% pembentukan karakter tanggung jawab.

Pembentukan karakter bersahabat atau komunikatif melalui ISMUBA di Kelas IV SD Muhammadiyah Pangkalpinang sudah berjalan dengan baik dengan hasil persentase $82 \%$ pembentukan karakter bersahabat atau komunikatif.

\section{DAFTAR PUSTAKA}

Agustinova, Danu Eko. 2015. Memahami Metode Penelitian Kualitatif Teori \& Praktik. Yogyakarta: Calpulis.

Boedhowi. 2017. Petunjuk Teknis Implementasi Kurikulum Al-Islam, Kemuhammadiyahan dan Bahasa Arab (ISMUBA) pada Sekolah/Madrasah Muhammadiyah. Jakarta.

Daryanto, Darmiatun, Suryatri. 2013. Implementasi Pendidikan Karakter di Sekolah. Yogyakarta: Gava Media.

Salahudin, Anas. 2011. Filsafat Pendidikan. Bandung: CV Pustaka Setia.

Sugiyono. 2015. Memahami Penelitian Kualitatif. Bandung: CV Alfabeta.

Sugiyono. 2017. Metode Penelitian Kuantitatif, Kualitatif, dan $R$ \& $D$. Bandung: CV Alfabeta.

Yaumi, Muhammad. 2016. Pendidikan Karakter Landasan, Pilar, dan Implementasi. Jakarta: Prenada Media Group. 